Article

\title{
Effectiveness of Protected Areas in the Pan-Tropics and International Aid for Conservation
}

\author{
Do-Hyung Kim ${ }^{*}$, Anupam Anand ${ }^{2}$ \\ 1 Office of Innovation, United Nations Children's Fund; dokim@unicef.org \\ 2 Independent Evaluation Office, The Global Environment Facility; aanand2@thegef.org \\ * Correspondence: dokim@unicef.org
}

\begin{abstract}
Evaluation of the effectiveness of protected areas is critical for forest conservation policies and priorities. To evaluate their effectiveness, we used $30-\mathrm{m}$ resolution forest cover change data between 1990 and 2010 for $\sim 4,000$ protected areas and analyzed the relationships of the effectiveness of protected areas with socio-economic variables. Our results show that protected areas in the Tropics avoided $83,500 \pm 21,200 \mathrm{~km}^{2}$ of deforestation during the 2000s. Brazil's protected areas have the largest amount of avoided deforestation of $50,000 \mathrm{~km}^{2}$. We also show the amount of international aid received by tropical countries compared to the effectiveness of protected areas. International aid had major benefits in Latin America led by Brazil while tropical Asian countries used the resource ineffectively. Our results demonstrate that protected areas have been relatively more efficient in countries where deforestation pressures were increasing, and governance and forest change monitoring capacity are important factors for enhancing the efficacy of international aid.
\end{abstract}

Keywords: Protected area, tropical deforestation, international aid, conservation, remote sensing

\section{Introduction}

In 2010, the Convention on Biological Diversity (CBD) adopted a revised strategic plan for biodiversity for 2011-2020 including the Aichi Biodiversity Targets. One of the targets is to reduce the rate of loss of all natural habitats including forest by 2020 (1). However, recent studies $(2,3)$ have shown acceleration and high sustained rates of tropical deforestation since 2000. To meet the proposed goals of conservation plans such as the Aichi Biodiversity Targets, evaluation of the effectiveness of previous and current efforts to reduce tropical deforestation is essential. Within this context, assessment of the effectiveness of Protected Areas (PAs) throughout the tropics is relevant given that PAs are central to climate and biodiversity policies (4-6). Previous efforts have been made to evaluate the effectiveness of PAs over various spatial and temporal scales $(4,5,7-10)$. Some studies has been done to evaluate the cost-effectiveness of these PAs $(11,12)$, exploring the links between the value of PAs and surrounding socio-economic drivers of tropical deforestation (13). Some others have examined the management effectiveness of PAs for limited times and spatial scales (14). Satellite based remotely sensed data have been used to evaluate the effectiveness of PAs in reducing deforestation because of their spatio-temporal consistency and its capability of complementing ground-based observations including filling of data gaps and solving compatibility issues $(4,15,16)$. However, spatially explicit information on pan-tropical forest cover change at Landsat resolutions has not previously been available beyond satellite analysis in selected locations $(4,17)$. Lack of comprehensive long-term spatial data has precluded pan-tropical scale analysis on the effectiveness of PAs in terms of their regulating socio-economic factors. Long term, large-area forest cover change at 30-m resolution has been recently made available (18-20). Based on this information, this study aims to, 1) estimate avoided deforestation by PAs in each tropical country during the 2000s, 2) compare the avoided deforestation against international aid for biodiversity conservation received by each tropical country 3) analyze the relationships between the socio-economic variables and increases in deforestation, avoided deforestation by PAs at country level. 


\section{Experimental Section}

\section{Forest change data}

Landsat based forest cover change data between 1990, 2000, and $2010(3,18,19)$ were used to derive net forest cover change in 34 tropical countries that comprise over $80 \%$ of forest area in the tropics (3), and dominates the forest area of the humid tropics. These data were derived from 5,444 surface reflectance images collected for the 1990, 2000, and 2010 epochs from the Global Land Survey (GLS) collection of Landsat images (21-24) supplemented by many additional images (21). Forest cover was defined as parcels $>1$ ha in area and comprising pixels with $>30 \%$ tree cover (25-27) and with the International Geosphere-Biosphere Programme's (IGBP) classes of forest ( $>60 \%$ tree cover) and woody savannas ( $>30 \%$ tree cover) combined.

\section{Socio-economic data}

Previous studies have shown the significant impact of population growth, increased agricultural production and agricultural trade on tropical deforestation (28-30). In this study, we used various sources of demographic, economic and agricultural statistics to examine the relationships with increased rates of deforestation between the 1990s and 2000s, and with effectiveness of PAs (Table 1).

Table 1. Socio-economic variables and data sources for regression analysis.

\begin{tabular}{cc}
\hline Data & Sources \\
\hline Agricultural production & FAO, 2012 \\
Export of agricultural product & FAO, 2012 \\
Trade of agricultural product & FAO, 2012 \\
Urban population & FAO, 2012 \\
Rural population & FAO, 2012 \\
Gross domestic product & World Bank, 2015 \\
Rule of law & World Bank, 2013 \\
Control of corruption & World Bank, 2013 \\
Monitoring capacity & Romijin et al (44) \\
International aid & AidData (27) \\
\hline
\end{tabular}

Although the forest change data used in this analysis is of comparatively high spatial resolution, there is not enough socio-economic data at this resolution for the tropics. This limits the scale of this study to a country level. At this coarse scale, the relationships between individual PAs and geophysical factors (e.g., terrain characteristics, distance to edge) were not taken into account. National scale data from United Nations Food and Agriculture Organization (FAO) were used to derive demographic and agricultural statistics (31). The Worldwide Governance Index (WGI) (32) reports governance indicators for countries over the period 1996-2013. We used two indicators, the 'Rule of law', which is a measure of the ability to enforce the law and 'control of corruption', which measures perceptions of the extent to which public power is exercised for private gain.

\section{International aid data for biodiversity conservation}

Global aid data for the period 1990- 2010 was obtained from AidData Version 3 database (33). The database contains records of development projects from more than 90 bilateral and multilateral donors, and constitutes a detailed source of project-level information on international aid (33). We used the nominal value of currency (in US dollars) to account for changes in the value of currency over time. The project data extracted from AidData includes data from all the sectors (34). We excluded the sectors less relevant for biodiversity and natural resource management such as reproductive health care and secondary education. Averages for the 1990s and the 2000s were calculated from each data set and the differences are used as independent variables for regression analysis. 


\section{Forest cover change rate inside and outside $P A s$}

We extracted the forest cover change maps for each of the 3,888 designated PAs and their surrounding areas in 34 tropical countries (35) from the Landsat-based forest cover change data. We analyzed the entire designated PAs in the tropical countries instead of using any sampling to take a full advantage of the spatially explicit, fine resolution data. In spite of the conceptual importance, the effects from Protected Areas downgrading, downsizing and degazettemnt (PADDD) $(36,37)$ are not considered in this study since there are only small number (4) of relevant PADDD are identified from the avaliable PADDD data (38). We derived the annual gross forest loss, gross forest gain and net forest change rates within each PA and its surrounding area from the forest change maps. We then calculated the forest loss rate by dividing the area of forest loss by area of forest within PAs or surrounding areas. Each GLS epoch spans a range of years focused on the nominal year (23), so the forest/nonforest layer in each year was accompanied by the year of image acquisition to estimate changes over time as rates.

\section{Estimation of Avoided Deforestation by PAs}

Measuring the amount of avoided deforestation by PAs is complex because it cannot be measured directly (7). Broadly, two different approaches have been in use to estimate avoided deforestation. The first set of approaches compare differences in forest change rate between the inside and outside of PAs $(4,5,15)$. These, however, have been criticized for their inability to account for the spillover effect from PAs to the adjacent areas outside of PAs and for selection bias due to unrandomized selection of PAs and inherently different deforestation probability between the inside and outside of PAs (39). Second, there are statistical matching approaches to match the difference of deforestation probability between samples inside and outside PAs $(7,9)$. The statistical matching of samples is robust, but hard to implement due to high computational cost and difficulties in finding statistically significant matches especially when the PA network covers large continuous tracts of land (12), and some important factors, such as policies (e.g. concession), which contribute to deforestation probability can be overlooked. To avoid selection bias and computational difficulties associated with previously mentioned methods, we used the Difference-In-Difference (DID) estimator to measure avoided deforestation in the 2000s compared to the 1990s for PAs in each tropical country $(40,41)$ (Figure 1$)$.

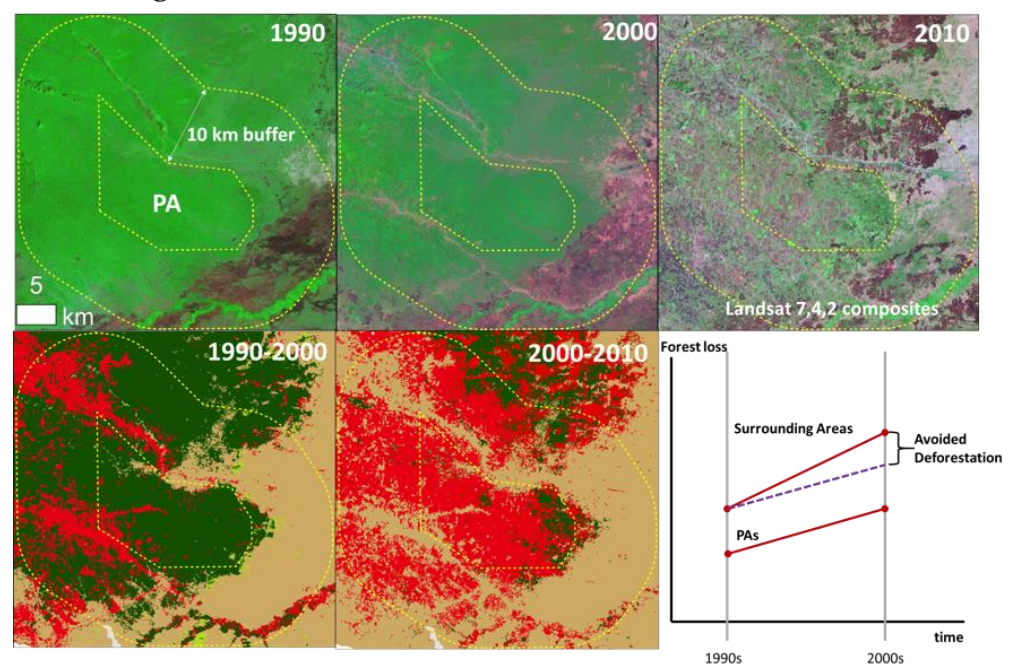

Figure 1. Avoided deforestation estimates for a designated protected area in Cambodia. Top images show forest change over time in the Roniem Daun Sam wildlife sanctuary designated in 1993 in Cambodia. Bottom figures show forest cover change maps between periods and an illustration of DID method. Avoided deforestation (DID) is calculated by taking differences between difference in forest loss rate in the PAs before and after designation and the difference in forest loss rate in the surrounding areas over time. 
This method has a relatively strong inferential ability as it eliminates selection biases by attempting to mimic an experimental research design using observational data $(40,42)$. The impact of a treatment on an outcome $\mathrm{Yi}$, annual forest change rate in this study was modeled by the following equation:

$$
Y i=\alpha+\beta T i+\gamma t i+\delta(T i \cdot t i)+\varepsilon i
$$

Where, $\mathrm{T}$ is the treatment status, $\mathrm{t}$ is the time period before and after the treatment, the coefficients given by the Greek letters $\alpha, \beta, \gamma, \delta$ are all unknown parameters and $\varepsilon_{\mathrm{i}}$ is a random, unobserved "error" term. In the DID estimator, the effect of treatment (avoided deforestation), $\delta$, is defined as the difference in average outcome in the treatment group $\mathrm{T}$ before and after treatment minus the difference in average outcome in the control group $\mathrm{C}$ before and after treatment and expressed as:

$$
\delta=\bar{Y}_{1}^{T}-\bar{Y}_{0}^{T}-\left(\bar{Y}_{1}^{C}-\bar{Y}_{0}^{C}\right)
$$

Where, the treatment group is PAs and the control group is surrounding areas before and after the year 2000 (Figure 1). We applied this method to a) the 3,888 PAs and surrounding areas designated prior to 2010 to determine the accumulated effect during the 2000s, and b) to the subset of 1,253 PAs established between 2000 -2010 to estimate the effect of newly established PAs.

\section{Estimation of Spillover effect}

Spillover effect refers to displacement of forest loss from one place to a neighboring area due to the establishment of a PA. If PAs displaced deforestation to immediate surrounding areas through the spillover effect, deforestation rate increases within immediately surrounding areas will be higher than in other regions with similar characteristics (e.g. accessibility) $(16,43)$. Based on these assumptions, we measured the potential spillover or leakage effect by comparing forest loss between the 1990s and the 2000s and avoided deforestation estimates using surrounding areas at different buffer distances $(500 \mathrm{~m}, 1 \mathrm{~km}, 5 \mathrm{~km}, 10 \mathrm{~km}, 15 \mathrm{~km}, 20 \mathrm{~km}$ and $25 \mathrm{~km})$.

\section{Statistical Analysis}

To ensure the robustness of DID method, we tested 1) Ordinary least squares (OLS) regression analysis between treatment, time period, and estimated avoided deforestation as expressed in equation (1); 2) paired t-test between the difference in forest loss rates in PAs and the difference in forest loss rates in the surrounding areas to determine significance of the effect of PAs before and after 2000. Effects of PAs are graphically presented with changes in frequency distributions. Variables for the regression analysis were selected based on variation inflation factor, which account for collinearity (28). All independent variables were log transformed. We used a minimum node size of three, for both regression trees and random forest analysis to minimize residual deviance. $R$ packages CAR and TREE are used for the collinearity check and regression tree analysis respectively.

\section{Results and Discussion}

\section{Avoided Deforestation by Protected Areas}

Our results demonstrate an overall $83,500 \pm 21,200 \mathrm{~km}^{2}$ of avoided deforestation by the PAs during the 2000s throughout the tropics, which equals $3.5 \%$ of all forest area within PAs in the study area (Figure 2). 


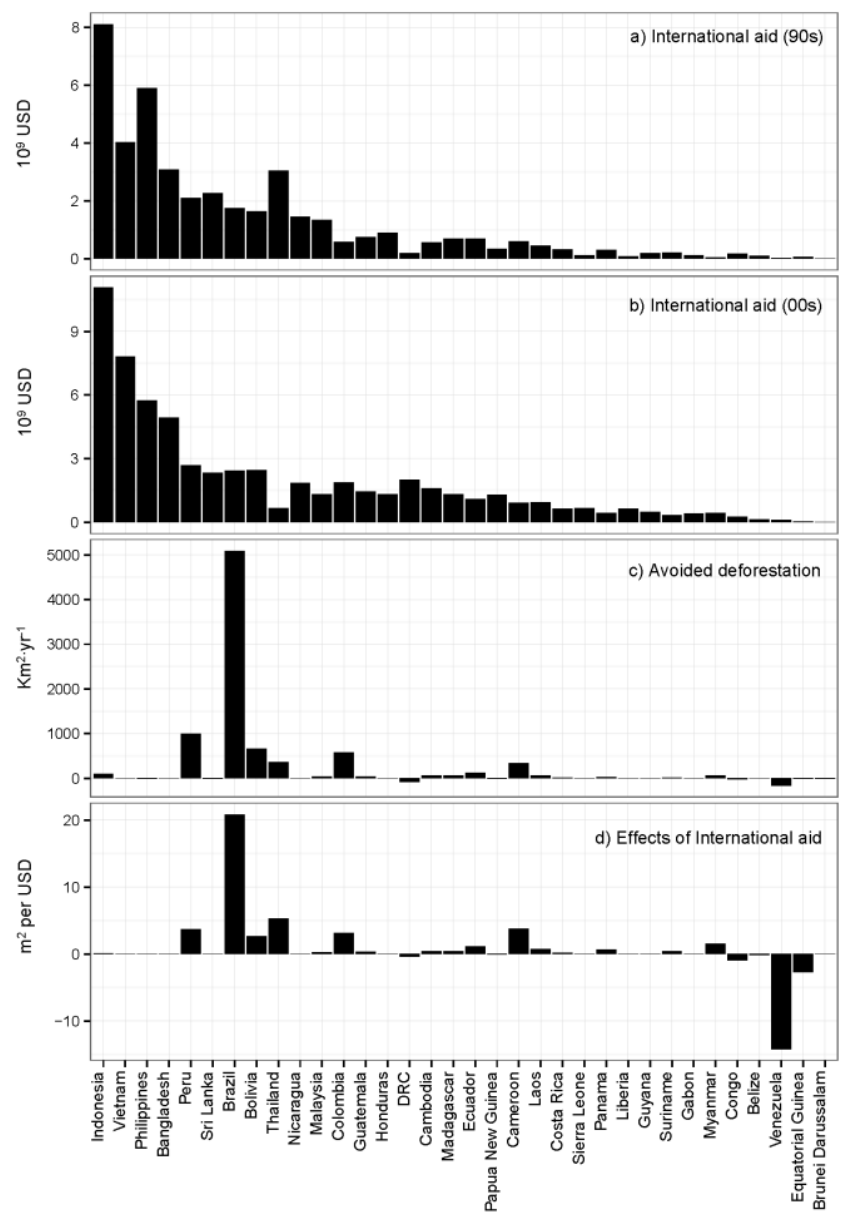

Figure 2. The amount of international funds committed to each tropical country in the 1990s (a) and the 2000s (b), the amount of funds are converted to a nominal value of US dollar. Avoided deforestation by each country (c). Effects of International aid (amount of international aid per unit of avoided deforestation) for 34 tropical countries (d).

Latin America showed the largest estimates of avoided deforestation during the 2000s $(73,900$ $\left.\mathrm{km}^{2}\right)$. In Latin America, Brazil showed the largest avoided deforestation $\left(50,870 \mathrm{~km}^{2}\right)$, followed by Peru $\left(9,970 \mathrm{~km}^{2}\right)$, and Bolivia $\left(6,611 \mathrm{~km}^{2}\right)$ for the same time- period. Venezuela was found to have the largest negative effect $\left(-1,622 \mathrm{~km}^{2}\right)$ among Latin American countries. Negative effect means forest loss rates within PAs exceeded the forest loss rates in surrounding areas. Relatively high rates of avoided deforestation from PAs in Brazil emphasize the important role of Brazil in tropical forest conservation. Positive avoided deforestation effects of PAs in Brazil were also reported by previous studies $(12,13)$. Tropical Asia showed the second largest estimates of avoided deforestation of 6,744 $\mathrm{km}^{2}$, with the largest amount in Thailand followed by Indonesia. Tropical Africa has the lowest estimates, except Cameroon, which showed the largest estimate of $3,411 \mathrm{~km}^{2}$. In terms of the percentage of avoided deforestation against the entire forest area in PAs, Africa showed the lowest estimates of $1.8 \%$ while Latin America and Asia showed similar estimates of $3.8 \%$. The comparison between estimates for the entire set of PAs and for the PAs established after 2000 showed that PAs established post 2000 had a higher rate of avoided deforestation at $0.5 \%$ annually compared to $0.4 \%$ for the entire set of PAs. The area of avoided deforestation by PAs established during the 2000s was about $60 \%$ of estimated avoided deforestation by all PAs in the study area. On average, PAs in the tropics established after 2000 showed a greater avoided deforestation than PAs established before 2000. Nevertheless, old established PAs were still effective, just not as much as recently established ones (41). Estimates of avoided deforestation based on the median value of forest loss exhibited 
similar results. Changes in mean and median forest loss within PAs and the surrounding areas before and after 2000 demonstrate the positive effects of PAs on reducing deforestation (Table 2).

Table 2. Estimates of Avoided deforestation by time of establishment of PAs. Numbers in parenthesis represent estimates using median forest loss rate.

\begin{tabular}{ccccccc}
\hline & \multicolumn{2}{c}{ Avoided deforestation } & \multicolumn{2}{c}{$\begin{array}{c}\text { Mean forest loss rate } \\
\text { within PAs }\end{array}$} & \multicolumn{2}{c}{$\begin{array}{c}\text { Mean forest loss rate within } \\
\text { BZs }\end{array}$} \\
\hline $\begin{array}{c}\text { Year of } \\
\text { establishment } \\
\text { Prior to } 2010\end{array}$ & $\begin{array}{c}\text { 3\%) } \\
\text { 3.46(4.1) }\end{array}$ & 83,500 & $0.59(0.09)$ & $1.65(0.17)$ & $0.91(0.46)$ & $2.32(0.94)$ \\
$1990-2000$ & $3.42(4.6)$ & 22,800 & $0.5(0.01)$ & $1.66(0.02)$ & $0.86(0.46)$ & $2.32(1)$ \\
$2000-2010$ & $4.47(5)$ & 47,650 & $0.5(0.02)$ & $1.52(0.04)$ & $0.897(0.35)$ & $2.37(0.87)$ \\
\hline
\end{tabular}

The lower deforestation rates in recent PAs and the higher rates in the recent surrounding areas after 2000 shows that, the greater avoided deforestation of recent PAs is not because of their remoteness (Table 2). Congo, Belize, the Philippines and Sri Lanka showed positive avoided deforestation from PAs established since 2000, while estimates including all PAs established before 2000 showed negative effects in these countries, suggesting the old established PAs in those countries are experiencing higher rates of deforestation. Our estimates of avoided deforestation are supported by following analysis. First, the Ordinary Least Sqaure (OLS) regression analysis of the PA effect evaluation model (equation 1$)$ shows a strong association $(p<0.001)$ between forest loss rate change and protected area designation (Table A2). Second, paired t-test between the forest loss rate changes in PAs and the surrounding areas confirms the hypothesis that two groups show a significant difference before and after the designation of PAs $(t=6.6)$. Third, Figure 3 suggests that at $t 1$ (pre2000), the forest loss rate was high inside PA area and at 2 (post 2000) loss was lower confirming the positive effects of PAs in the tropics in reducing deforestation.
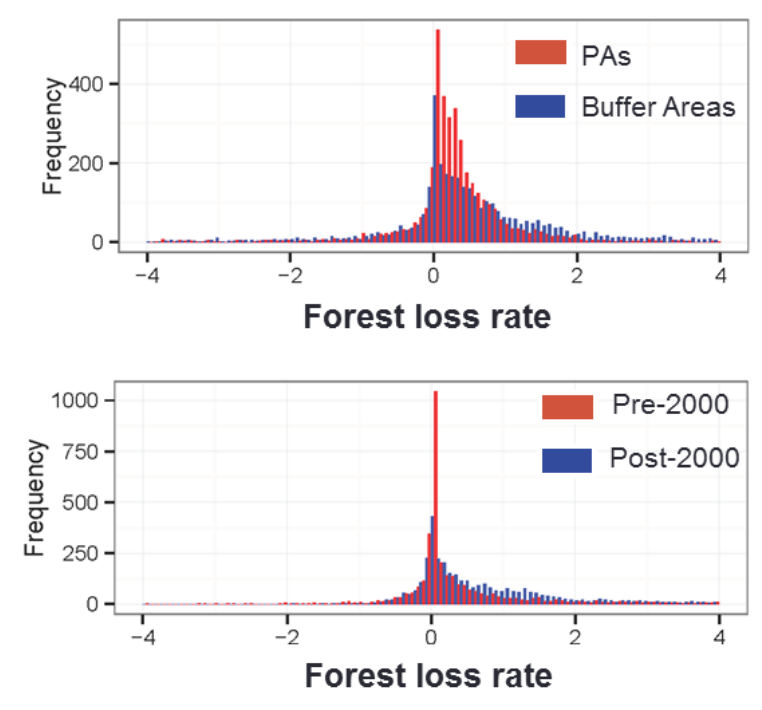

Figure 3. Frequency distribution of the difference in forest loss rates between the interior of protected areas and the surrounding $10 \mathrm{~km}$ buffers in the 1990s (t1) (Blue) and the 2000s (t2) (Red). The figure suggests that at $\mathrm{t} 1$, the forest loss rate was high inside PA area (before 2000) and at $\mathrm{t} 2$ loss was lower.

Finally, our results show that PAs in Brazil established since 2000 avoided deforestation of 2,794 $\mathrm{km}^{2}$ annually which is corroborated by an annual $2,500 \mathrm{~km}^{2}$ of avoided deforestation between 2004 and 2006 reported by Soares-Filho et al. (12). Figure 4 shows mean forest loss rates of surrounding areas with various distances from $500 \mathrm{~m}$ to $25 \mathrm{~km}$ from PAs at the 1990s (a) and at the 2000s (b). 


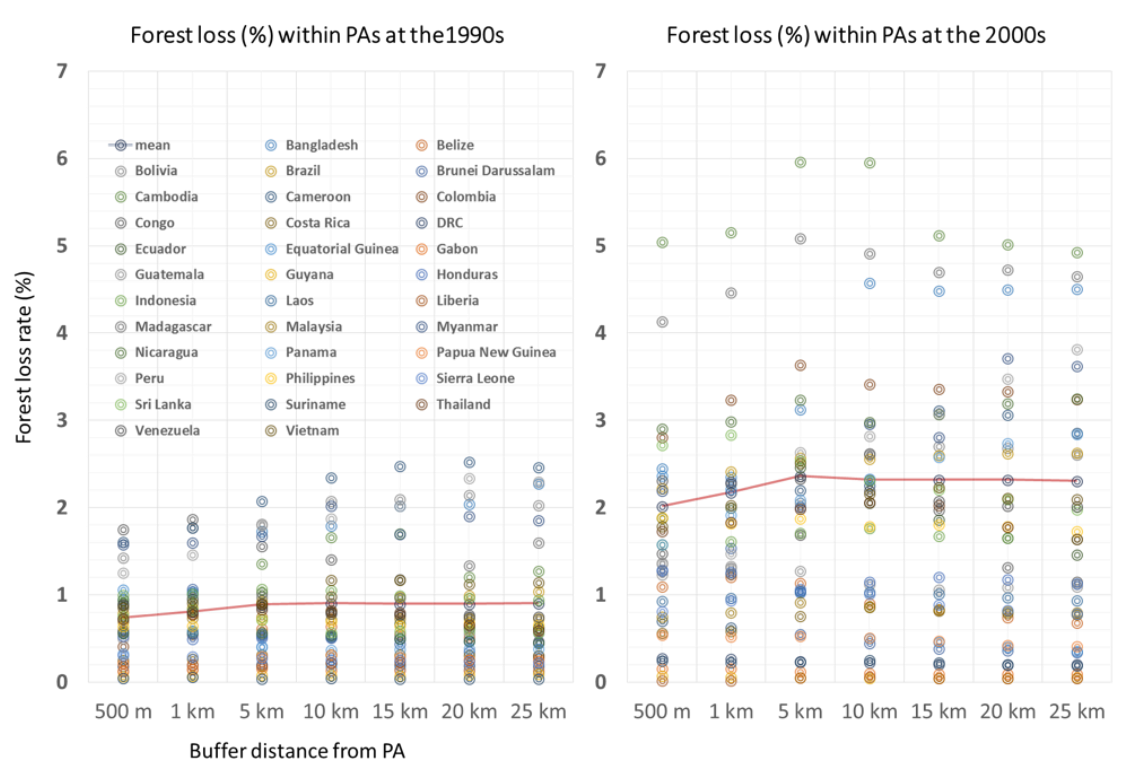

Figure 4. Mean forest loss rate at surrounding areas with various buffer distances at the 1990s and at the 2000s in each country. Red line shows the mean forest loss at each period.

Figure 4 demonstrates that the increase in forest loss between two decades was largest within $10 \mathrm{~km}$ distance. This suggests that the spill-over effects were largest in the immediately adjacent area to the PAs and the area farther than $10 \mathrm{~km}$ from PAs had marginal spill-over effects. Spillover effect refers to displacement of forest loss from PAs to surrounding areas due to the establishment of PAs. Relatively lower forest loss rates within surrounding areas with less than $10 \mathrm{~km}$ buffer distance are because of its relative inaccessibility, isolation (4) or even better protection due to buffer zone conservation initiatives (44). We used estimates of avoided deforestation with a $10 \mathrm{~km}$ buffer distance for the regression analysis where the spill-over effects start to be marginal.

\section{International aid for conservation}

34 tropical countries received a total international aid for biodiversity conservation of 42 billion USD during the1990s and 62 billion USD during the 2000s, with a net increase of $46 \%$ (20 billion USD) between two periods (Figure 1). Among continents, Tropical Asian countries were the largest recipients, receiving $62 \%$ of all funds during the 2000s, followed by Latin American countries (28\%). Among the countries, Indonesia received the largest amount of aid, $18 \%$ of all funds received by 34 tropical countries, followed by Vietnam (12\%) and the Philippines (9\%) for the same period (29).

In order to compare the avoided deforestation against international aid for biodiversity conservation received by each tropical country, we determined the relative contribution of the international aid - 'effectiveness of international aid,' by dividing estimated avoided deforestation area with amount of international aid for biodiversity conservation received by each country. The rationale for this assumption is that 1) the primary goal of international aid for biodiversity conservation is to enhance the conservation of biodiversity regardless of the political and economic circumstances and 2) conservation of biodiversity in the tropics has a negative association with tropical deforestation $(6,28,33)$. However, we are not intended to analyze causal relationships between the avoided deforestation and the amount of the international aid.

The effectiveness of international aid was highest in Latin America with $4.3 \mathrm{~m}^{2} / \mathrm{USD}$, led by Brazil, while tropical Asian countries showed the lowest average effect of international aid of 0.17 $\mathrm{m}^{2} / \mathrm{USD}$. Among the countries, Brazil showed the absolute highest cost-effect of $21 \mathrm{~m}^{2} / \mathrm{USD}$. The blue line in Fig. 1 indicates that only 9 out of 34 countries were found to have higher effects of international aid than average. County based estimates of avoided deforestation by PAs and effects of international aid showed a various pattern throughout the Tropics. Notably, two largest sources of tropical 
deforestation during the 2000s, Brazil (2.2 Mha $\left.\cdot \mathrm{yr}^{-1}\right)$ and Indonesia (0.8 Mha $\left.\cdot \mathrm{yr}^{-1}\right)$, showed a sharp contrast (3). Brazil showed higher estimates of avoided deforestation compared to Indonesia by a factor of 50 although Indonesia has received about $500 \%$ more international aid (11 billion USD) compared to Brazil (2.4 billion USD) resulting in lower estimates of effects of international aid (0.5 $\mathrm{m}^{2} / \mathrm{USD}$ ) compared to Brazil (22 $\mathrm{m}^{2} / \mathrm{USD}$ ) by a factor of 44 .

\section{Socio-economic drivers}

We used multiple linear regression and regression tree algorithms to identify linear and nonlinear relationships between forest loss change, avoided deforestation, effect of international aid and, potential socio-economic drivers $(30,45-47)$. Our aim was to identify factors most strongly associated with each variable rather than to make predictions. We used multiple linear regression to identify general relationships between variables, and variables with significant associations $(P<0.05)$. Complementarily, we used regression tree and random forest methods implemented in $\mathrm{R}$ to ensure robustness of analysis and to find any important non-linear relationships $(48,49)$. Table 5 summarizes the results of regression analysis based on multiple linear regression and regression tree analysis. Multiple linear regressions showed mild to moderate correlations $\left(0.2<\mathrm{r}^{2}<0.5\right)$ and significant associations $(P<0.05)$ between independent variables and driving forces.

Multiple regression analysis between the 'difference of annual forest loss rate between the 1990s and the 2000s' and potential driving forces showed an overall moderate correlation $\left(\mathrm{r}^{2}=0.44\right)$ and significant association $(\mathrm{p}<0.001)$. There is a significant $(\mathrm{P}<0.01)$ positive association between 'difference of annual forest loss rate between the 1990s and the 2000s' and 'difference of annual agricultural production growth rate between the 1990s and the 2000s'. This shows that agricultural intensification, evidenced in Mato Grosso in Brazil (50) may not be prevalent throughout the tropics (45). A highly significant ( $\mathrm{p}<0.001)$, negative association exists between 'differences of annual forest loss rate between the 1990s and the 2000s' and 'difference of annual Gross Domestic Product (GDP) growth rate between the 1990s and the 2000s'. This result demonstrates that countries with fewer resources for economic development during the 2000s were under higher pressure to deforest (5052). There is a significant $(\mathrm{p}<0.01)$ negative association between the 'difference of annual forest loss rate between the 1990s and the 2000s' and the 'difference of urban population increase rate between the 1990s and the 2000s'. Previously, Defries et al. (30) have demonstrated that agricultural export and urban population growth were the most dominant drivers of tropical forest loss between 2000 and 2005. The 'difference of annual GDP growth rate' was the first split in the regression tree, which means that GDP growth is the most powerful discriminator between countries. Multiple regression analysis indicated a mild correlation $\left(\mathrm{r}^{2}=0.32\right)$ between the 'amount of avoided deforestation by PAs' and the 'difference of annual forest loss rate between the 1990s and 2000s'. Both multiple regression analysis and regression tree analysis showed that 'annual forest loss rate between the 1990s and 2000 s' was significantly associated with 'avoided deforestation by PAs'. The pronounced positive association $(\mathrm{p}<0.0001)$ exhibited by the regression analysis between 'avoided deforestation from PAs' and 'increase in deforestation rate between the 1990s and the 2000s' (Table 3) suggests that protected areas have been effectively established where deforestation is accelerating. Latin American countries showed higher rates of avoided deforestation compared to the increased forest loss rate although it cannot be ascertained if it is due to proper allocation of PAs, or that PAs in Latin American countries are more effectively managed.

The 'effectiveness of international aid' shows mild correlation $\left(\mathrm{r}^{2}=0.25\right)$ with 'difference of annual agricultural production growth rate between the 1990s and the 2000s', 'rule of law' and 'monitoring capacity'. Regression tree analysis shows that 'rule of law' makes the first split and the next split is made by 'monitoring capacity'. This is especially demonstrated by 3 countries including Democratic Republic of Congo, Myanmar and Venezuela with the lowest effect of international aid and the lowest value of rule of law, which is an indicator of the ability to enforce the law. These results emphasize the importance of good governance in enhancing the effectiveness of international aid. This finding is consistent with studies (34) that illustrate that aid agencies have a preference for countries with good governance. The results also demonstrate the possibilities of satellite-based 
forest loss monitoring to supplement and enhance the process of allocation of conservation efforts and resources.

Table 3. Results of regression analysis based on different techniques including multiple linear regression, regression tree algorithm.

\begin{tabular}{|c|c|c|c|c|}
\hline $\begin{array}{l}\text { Independent } \\
\text { variables }\end{array}$ & Multiple linear regression & $\mathbf{R}^{2}$ & $\mathbf{P}$ & Regression Tree \\
\hline $\begin{array}{l}\text { Difference of annual } \\
\text { forest loss rate } \\
\text { between the 1990s } \\
\text { and the 2000s }\end{array}$ & $\begin{array}{l}\text { GDP growth }{ }^{* * *} \\
\text { Difference of annual agricultural } \\
\text { production growth rate between } \\
\text { the 1990s and the 2000s } s^{* *} \\
\text { urban population growth }\end{array}$ & 0.44 & $<0.001$ & $\begin{array}{l}\text { GDP growth, } \\
\text { urban population growth }\end{array}$ \\
\hline $\begin{array}{c}\text { Avoided } \\
\text { deforestation }\end{array}$ & $\begin{array}{l}\text { Difference of annual forest loss rate } \\
\text { between the 1990s and the 2000s }\end{array}$ & 0.32 & $<0.05$ & $\begin{array}{l}\text { Difference of annual } \\
\text { forest loss rate between } \\
\text { the 1990s and the 2000s }\end{array}$ \\
\hline $\begin{array}{l}\text { Effectiveness of } \\
\text { international aid }\end{array}$ & $\begin{array}{l}\text { Agricultural production growth } \\
\text { Rule of law } \\
\text { Ronitoring }^{* *}\end{array}$ & 0.25 & $<0.05$ & Rule of law \\
\hline${ }^{*} \mathrm{P}<0.01 \quad * * \mathrm{P}<0.001$ & $* * * \mathrm{P}<0.0001$, independent variable & are lo & transfor & \\
\hline
\end{tabular}

Our approach using DID estimator with fine resolution, spatially explicit forest change data offered an alternative way to handle the commonly criticized selection bias and spillover problems $(7,39)$. In spite of methodological advances made in this study, our study has some limitations. First, our estimates of forest cover change do not distinguish between primary and managed forests, thus leaving a potential for confusion between loss of natural forest and managed harvest. Second, the coarse spatial scale of socio-economic data limited the regression analysis to the country scale that in turn prevented the regression analysis between individual PAs and their geophysical factors. Third, Brazil's success in reducing deforestation is an exceptional case made possible under a special political landscape $(13,53)$, which is difficult to generalize to other tropical countries. Finally, for the estimates of the effect of international aid on avoided deforestation by PAs, we only considered the contribution of international monetary aid while the amount of international aid may not be the only factor that determines the effectiveness of PAs. Other domestic sources of funds (e.g. Amazon Region Protected Areas Program of Brazil) and different aspects of conservation (e.g. biodiversity) or political environment, which vary by country and over time were not accounted for in this study. Also, the processes of international aid delivery were not considered in this study. For example, Norwegian funds are committed to Indonesia under the condition that they meet specific conservation goals. Further analysis is needed to estimate the effects of differences in the distribution of funds.

\section{Conclusions}

Our results showed an overall positive effect of pan-tropical PAs on reducing deforestation during the 2000s. The overall positive effect of PAs in reducing deforestation throughout the tropics corroborates with previous studies $(7,41,54-56)$. However, unlike many previous studies, our results provide a consistent, long-term estimate throughout the pan-tropics. The results of the estimated avoided deforestation and effects of international aid by countries pinpoint where the conservation activity and resources distribution are effectively practiced and helps establish the link to socioeconomic factors and their significance and underlying implications. Our analysis showed that, the increase in deforestation rate between the last two decades were positively and significantly associated with increases in GDP growth rate, agricultural production growth, and urban population growth; PAs that were established in areas with high deforestation rates were relatively more effective; the effectiveness of international aid can be suppressed by weak governance and lack of forest change monitoring capacity in each country. These patterns and links underscore the challenges that policy instruments face and also provide a launch pad for alternative strategies for 
future conservation polices and initiatives. Nevertheless, with robust empirical approach and future availability of data on socio-economic drivers, the protection of critical ecosystem services in a coupled human-natural system can be better understood.

Author Contributions: D.K. and A.A. equally contributed to the manuscript.

Funding: Funding support for this study was provided by the following NASA programs: Making Earth System Data Records for Use in Research Environments (NNH06ZDA001N-MEASURES), Land Cover and Land Use Change (NNH07ZDA001N-LCLUC), and Earth System Science Research Using Data and Products from Terra, Aqua, and Acrimsat Satellites (NNH06ZDA001N-EOS)

Acknowledgments: Rachel Headley (USGS) sent the GLS datasets to the GLCF. Min-Kyung Shin assisted collection and processing of socio-economic data. The opinions expressed in this article may not reflect the opinions of UNICEF and the Global Environment Facility.

Conflicts of Interest: The authors declare no conflict of interest.

\section{Appendix A}

Table A1. Summary of the avoided deforestation estimates by countries and continents. Acceleration of deforestation is indicated by percent increase in net deforestation rate from the 1990s to the 2000s (3), Avoided deforestation as presented in percent of conserved forest relative to remaining forest in PAs and total area of conserved forest. All estimates are on an annual basis. Negative effect means forest loss rates within PAs exceeded the forest loss rates in surrounding areas.

\begin{tabular}{|c|c|c|c|c|c|c|}
\hline Country & $\begin{array}{c}\text { Acceleration of } \\
\text { deforestation } \\
(\%)\end{array}$ & $\begin{array}{c}\text { Avoided } \\
\text { deforestation } \\
(\%) \\
\end{array}$ & $\begin{array}{c}\text { Avoided } \\
\text { deforestation } \\
\left(\mathbf{k m}^{2}\right) \\
\end{array}$ & $\begin{array}{c}\text { Area of } \\
\text { PAs }\left(\mathbf{k m}^{2}\right)\end{array}$ & $\begin{array}{l}\text { Forest area } \\
\text { in PAs (\%) }\end{array}$ & $\begin{array}{c}\text { No. of } \\
\text { PAs }\end{array}$ \\
\hline Cameroon & 20.6 & 1.39 & 341.1 & 46,414 & 53 & 35 \\
\hline Congo & 0.0 & -0.23 & -24.2 & 22,624 & 46 & 13 \\
\hline Democratic & 31.2 & -0.09 & -77.4 & 219,677 & 41 & 31 \\
\hline \multicolumn{7}{|l|}{ Republic Congo } \\
\hline \multicolumn{6}{|l|}{ Guinea } & 6 \\
\hline Gabon & -11.5 & 0.01 & 1.5 & 16,677 & 97 & 8 \\
\hline Liberia & -8.2 & -0.17 & -1.5 & 1,687 & 53 & 2 \\
\hline Madagascar & 15.6 & 0.69 & 57.5 & 15,322 & 55 & 42 \\
\hline Sierra Leone & 8.9 & 0.03 & 0.3 & 2,955 & 38 & 31 \\
\hline Africa Total & 6.8 & 0.18 & 286.5 & 328,957 & 47 & 168 \\
\hline Bangladesh & 16.3 & 0.17 & 0.5 & 490 & 56 & 19 \\
\hline Brunei & 0.0 & -0.90 & -3.8 & 448 & 94 & 18 \\
\hline \multicolumn{7}{|l|}{ Darussalam } \\
\hline Cambodia & 27.8 & 0.49 & 61.7 & 24,779 & 51 & 24 \\
\hline Indonesia & 2.9 & 0.22 & 100.8 & 95,981 & 49 & 152 \\
\hline Laos & 5.1 & 0.49 & 67.6 & 17,095 & 80 & 12 \\
\hline Malaysia & 2.5 & 0.21 & 38.4 & 19,330 & 96 & 122 \\
\hline Myanmar & 11.5 & 0.88 & 64.5 & 15,201 & 48 & 29 \\
\hline $\begin{array}{l}\text { Papua New } \\
\text { Guinea }\end{array}$ & 1.1 & -0.19 & -5.1 & 3,849 & 69 & 27 \\
\hline Philippines & 12.0 & -0.05 & -9.0 & 26,890 & 64 & 165 \\
\hline Sri Lanka & 19.5 & -0.05 & -3.0 & 11,860 & 46 & 210 \\
\hline Thailand & 15.9 & 0.76 & 357.1 & 61,541 & 76 & 117 \\
\hline Vietnam & 18.5 & 0.06 & 4.7 & 18,295 & 43 & 65 \\
\hline Asia Total & 11.1 & 0.38 & 674.4 & 295,758 & 61 & 960 \\
\hline Belize & -1.1 & -0.06 & -2.2 & 4,353 & 86 & 63 \\
\hline Bolivia & 5.6 & 0.92 & 661.1 & 98,585 & 73 & 42 \\
\hline Brazil & 3.3 & 0.34 & 5087.0 & $1,852,181$ & 82 & 1,321 \\
\hline
\end{tabular}




\begin{tabular}{ccccccc} 
Colombia & 18.0 & 0.89 & 582.9 & 169,960 & 38 & 593 \\
Costa Rica & 12.0 & 0.23 & 10.8 & 5,424 & 86 & 79 \\
Ecuador & 2.2 & 0.76 & 119.8 & 22,467 & 70 & 20 \\
Guatemala & 2.6 & 0.27 & 42.7 & 18,053 & 86 & 225 \\
Guyana & -6.2 & 0.01 & 0.6 & 10,426 & 41 & 3 \\
Honduras & 8.3 & 0.02 & 1.6 & 11,733 & 56 & 62 \\
Nicaragua & 26.5 & 0.68 & 9.4 & 4,597 & 30 & 61 \\
Panama & 18.8 & 0.76 & 27.3 & 4,610 & 78 & 13 \\
Peru & 4.5 & 0.51 & 997.0 & 308,599 & 64 & 185 \\
Suriname & 4.4 & 0.05 & 14.2 & 29,041 & 99 & 7 \\
Venezuela & 26.7 & -0.39 & -162.2 & 80,919 & 51 & 85 \\
Latin America & 9.0 & 0.38 & 7389.8 & $2,620,949$ & 75 & 2,759 \\
Total & & & & & & 71 \\
\hline Grand Total & 6.2 & 0.35 & 8350.6 & $3,245,663$ & & 3,887 \\
\hline
\end{tabular}

\section{Appendix B}

Table A2. Statistics of regression analysis for avoided deforestation by country and individual PA.

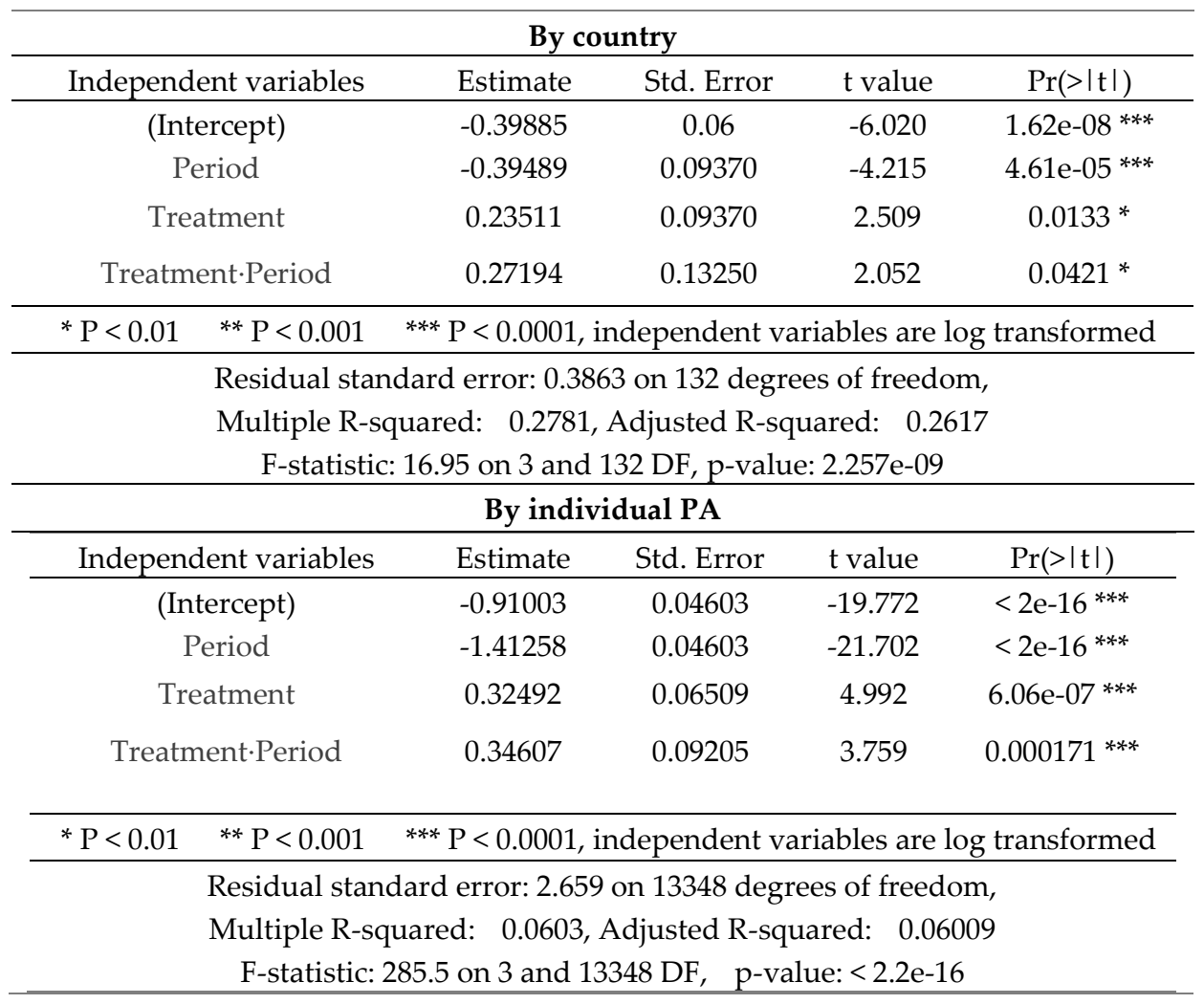

\section{References}

1. COP10 CBD. Strategic Plan for Biodiversity, 2011-2020. In: Conference of the Parties to the Convention on Biological Diversity, Nagoya, Japan. 2010.

2. Hansen MC, Potapov P V, Moore R, Hancher M, Turubanova SA, Tyukavina A, et al. High-resolution global maps of 21st-century forest cover change. Science (80- ). 2013;342(6160):850-3.

3. Kim D-H, Sexton JO, Townshend JR. Accelerated deforestation in the humid tropics from the 1990s to the 2000s. Geophys Res Lett. 2015;42(9):3495-501.

4. DeFries R, Hansen A, Newton AC, Hansen MC. Increasing isolation of protected areas in tropical forests over the past twenty years. Ecol Appl. 2005;15(1):19-26.

5. Joppa LN, Loarie SR, Pimm SL. On the protection of "protected areas". Proc Natl Acad Sci U S A. 
2008;105(18):6673-8.

6. Pimm SL, Ayres M, Balmford A, Branch G, Brandon K, Brooks T, et al. Can We Defy Nature 's End ? Science (80- ). 2001;293:2207-8.

7. Andam KS, Ferraro PJ, Pfaff A, Sanchez-Azofeifa GA, Robalino J a. Measuring the effectiveness of protected area networks in reducing deforestation. Proc Natl Acad Sci U S A. 2008;105:16089-94.

8. Huang C, Kim S, Song K, Townshend JRG, Davis P, Altstatt A, et al. Assessment of Paraguay's forest cover change using Landsat observations. Glob Planet Change. 2009;67(1):1-12.

9. Joppa LN, Pfaff A. Global protected area impacts. Proc Biol Sci. 2011;278(November 2010):1633-8.

10. Schmitt CB, Burgess ND, Coad L, Belokurov A, Besançon C, Boisrobert L, et al. Global analysis of the protection status of the world's forests. Biol Conserv. 2009;142(10):2122-30.

11. Kindermann G, Obersteiner M, Sohngen B, Sathaye J, Andrasko K, Rametsteiner E, et al. Global cost estimates of reducing carbon emissions through avoided deforestation. Proc Natl Acad Sci U S A. 2008;105:10302-7.

12. Soares-Filho B, Moutinho P, Nepstad D, Anderson A, Rodrigues H, Garcia R, et al. Role of Brazilian Amazon protected areas in climate change mitigation. Proc Natl Acad Sci U S A. 2010;107(11):10821-6.

13. Nolte C, Agrawal A, Silvius KM, Soares-Filho BS. Governance regime and location influence avoided deforestation success of protected areas in the Brazilian Amazon. Proc Natl Acad Sci U S A. 2013;110(13):4956-61.

14. Hockings M, Stolton S, Dudley N. Management Effectiveness: Assessing Management of Protected Areas? J Environ Policy Plan. 2004 Jun;6(2):157-74.

15. Curran LM, Trigg SN, McDonald AK, Astiani D, Hardiono YM, Siregar P, et al. Lowland forest loss in protected areas of Indonesian Borneo. Science (80- ). 2004;303(5660):1000-3.

16. Gaveau DLA, Epting J, Lyne O, Linkie M, Kumara I, Kanninen M, et al. Evaluating whether protected areas reduce tropical deforestation in Sumatra. J Biogeogr. 2009;36(11):2165-75.

17. Achard F, Eva HD, Stibig H-J, Mayaux P, Gallego J, Richards T, et al. Determination of deforestation rates of the world's humid tropical forests. Science (80- ). 2002;297(5583):999-1002.

18. Kim D, Sexton JO, Noojipady P, Huang C, Anand A, Channan S, et al. Remote Sensing of Environment Global , Landsat-based forest-cover change from 1990 to 2000. Remote Sens Environ [Internet]. 2014;155:178-93. Available from: http://dx.doi.org/10.1016/j.rse.2014.08.017

19. Sexton JO, Song X-P, Feng M, Noojipady P, Anand A, Huang C, et al. Global, 30-m resolution continuous fields of tree cover: Landsat-based rescaling of MODIS vegetation continuous fields with lidar-based estimates of error. Int J Digit Earth. 2013;6(5):427-48.

20. Townshend JR, Masek JG, Huang C, Vermote EF, Gao F, Channan S, et al. Global characterization and monitoring of forest cover using Landsat data: opportunities and challenges. Int J Digit Earth. 2012;5(5):373-97.

21. Channan S, Feng M, Kim D-H, Sexton JO, Song X-P, Song D-X, et al. The GLS+: An Enhancement of the Global Land Survey Datasets. Photogramm Eng Remote Sens. 2015;81(7):521-5.

22. Feng M, Sexton JO, Huang C, Masek JG, Vermote EF, Gao F, et al. Global surface reflectance products from Landsat: Assessment using coincident MODIS observations. Remote Sens Environ. 2013;134:27693.

23. Gutman G, Byrnes R, MASEK I, Covington S, Justice C, Franks S, et al. Towards monitoring changes at a Globa the Global Land S. Photogramm Eng Remote Sensing. 2008;74(1):6-10.

24. Masek JG, Vermote EF, Saleous NE, Wolfe R, Hall FG, Huemmrich KF, et al. A Landsat surface reflectance dataset for North America, 1990-2000. Geosci Remote Sens Lett IEEE. 2006;3(1):68-72. 
25. Belward AS. The IGBP-DIS Global $1 \mathrm{Km}$ Land Cover Data Set "DISCover": Proposal and Implementation Plans: Report of the Land Recover Working Group of IGBP-DIS. IGBP-DIS; 1996.

26. FAO. Proceedings, Expert Meeting on Harmonizing forest-related definitions for use by various stakeholders. In Rome, Italy; 2002.

27. UNFCCC. Report of the Conference of the Parties on its Seventh Session, held at Marrakesh from 29 October to 10 November 2001 [The Marrakesh Accords \& the Marrakesh Declaration]. Addendum Part two: Action taken by the Conference of Parties. Marrakesh, Morocco; 2002.

28. Myers N, Mittermeier RA, Mittermeier CG, Da Fonseca GAB, Kent J. Biodiversity hotspots for conservation priorities. Nature. 2000;403(6772):853-8.

29. Tierney MJ, Nielson DL, Hawkins DG, Roberts JT, Findley MG, Powers RM, et al. More dollars than sense: refining our knowledge of development finance using AidData. World Dev. 2011;39(11):1891-906.

30. DeFries RS, Rudel T, Uriarte M, Hansen M. Deforestation driven by urban population growth and agricultural trade in the twenty-first century. Nat Geosci [Internet]. 2010;3(3):178-81. Available from: http://dx.doi.org/10.1038/ngeo756

31. FAOSTAT. FAOSTAT. Food and Agriculture Organization of the United Nations Rome, Italy; 2012.

32. Indicator WG. Worldwide Governance Indicators. World Bank Acccesed. 2013;29.

33. Grainger A. Estimating areas of degraded tropical lands requiring replenishment of forest cover. Int Tree Crop J. 1988;5(1-2):31-61.

34. Miller DC, Agrawal A, Roberts JT. Biodiversity, Governance, and the Allocation of International Aid for Conservation. Conserv Lett. 2013;6:12-20.

35. IUCN U-W. The world database on protected areas (WDPA). UNEPWCMC, Cambridge, UK. 2010;

36. Mascia MB, Pailler S, Krithivasan R, Roshchanka V, Burns D, Mlotha MJ, et al. Protected area downgrading, downsizing, and degazettement (PADDD) in Africa, Asia, and Latin America and the Caribbean, 1900-2010. Biol Conserv [Internet]. 2014;169:355-61. Available from: http://dx.doi.org/10.1016/j.biocon.2013.11.021

37. Forrest JL, Mascia MB, Pailler S, Abidin SZ, Araujo MD, Krithivasan R, et al. Tropical Deforestation and Carbon Emissions from Protected Area Downgrading, Downsizing, and Degazettement (PADDD). Conserv Lett [Internet]. 2015;8(3):153-61. Available from: http://doi.wiley.com/10.1111/conl.12144

38. World Wildlife Fund. PADDDtracker.org Data Release Version 1.0 (January 2014). Washington, DC; 2014.

39. Stern M, Bhagwat S, Brown N, Evans T, Jennings S, Savill P, et al. Parks and factors in their success. Science (80- ). 2001;293(5532):1045-7.

40. Abadie A. Semiparametric difference-in-differences estimators. Rev Econ Stud. 2005;72(1):1-19.

41. Nelson A, Chomitz KM. Effectiveness of strict vs. multiple use protected areas in reducing tropical forest fires: a global analysis using matching methods. PLoS One. 2011;6(8):e22722.

42. Card D, Krueger AB. Time-series minimum-wage studies: a meta-analysis. Am Econ Rev. 1995;238-43.

43. Ewers RM, Rodrigues ASL. Estimates of reserve effectiveness are confounded by leakage. Trends Ecol Evol. 2008;23(3):113-6.

44. Alers M. Reducing threats to protected areas: lessons from the field. World Bank; 2007.

45. DeFries R, Herold M, Verchot L, Macedo MN, Shimabukuro Y. Export-oriented deforestation in Mato Grosso: harbinger or exception for other tropical forests? Philos Trans R Soc B Biol Sci. 2013;368(1619):20120173.

46. Rudel TK. Changing agents of deforestation: From state-initiated to enterprise driven processes, 19702000. Land use policy. 2007;24:35-41. 
47. Rudel TK, Defries R, Asner GP, Laurance WF. Changing drivers of deforestation and new opportunities for conservation. Conserv Biol. 2009;23(6):1396-405.

48. Breiman L. Random forests. Mach Learn. 2001;45(1):5-32.

49. Quinlan JR, Rivest RL. Inferring decision trees using the minimum description lenght principle. Inf Comput. 1989;80(3):227-48.

50. Geist HJ, Lambin EF. What drives tropical deforestation. LUCC Rep Ser. 2001;4:116.

51. Alvarez-Berríos NL, Mitchell Aide T. Global demand for gold is another threat for tropical forests. Environ Res Lett [Internet]. 2015;10(1):14006. Available from: http://dx.doi.org/10.1088/17489326/10/1/014006

52. Rudel T, Roper J. The paths to rain forest destruction: crossnational patterns of tropical deforestation, 1975--1990. World Dev. 1997;25(1):53-65.

53. Gibbs HK, Rausch L, Munger J, Schelly I, Morton DC, Noojipady P, et al. Brazil's Soy Moratorium. Science (80- ). 2015;347(6220):377-8.

54. Joppa LN, Pfaff A. Global protected area impacts. Proc R Soc B Biol Sci. 2010;rspb20101713.

55. Nagendra H. Do parks work? Impact of protected areas on land cover clearing. AMBIO A J Hum Environ. 2008;37(5):330-7.

56. Oliveira PJC, Asner GP, Knapp DE, Almeyda A, Galván-Gildemeister R, Keene S, et al. Land-use allocation protects the Peruvian Amazon. Science (80- ). 2007;317(5842):1233-6. 